\title{
ANNOUNCING
}

A LIMITED DELUXE EDITION

INTERBEHAVIORAL PHILOSOPHY

by

\section{J.R. Kantor}

The primary emphasis of this volume is to suggest a way to dispel the traditional animism which continues to underlie current philosophy and psychology. It is deplorable that the dualism of spirit and matter in philosophy and the mind-body bifurcation in psychology block the development of scientific attitudes in both disciplines. As the history of philosophy indicates, mythological attitudes engender a spurious philosophy which later forms the premise for a spiritistic psychology, which in turn is taken to be the support of transcendentalism in philosophy.

The author proposes a radical reconstruction of philosophy on a definite scientific foundation. The abolition of metaphysical conventions favors the view that philosophy consists of systems of attitudes derived only from observations of actually occurring events similar to those of established sciences.

\section{ORDER FORM}

The Principia Press

5743 Kimbark Avenue

Chicago, Illinois 60637

Enclosed find my check for $\$ 27.50$ for a postpaid copy of:

\section{Interbehavioral Philosophy}

by J.R. Kantor

Name

Address

City State Zip Code 